\title{
KETERAMPILAN PRESENTASI DENGAN KEMAMPUAN MENJAWAB TES LISAN PADA MAHASISWA PGSD UNRAM
}

\author{
Itsna Oktaviyanti \\ Universitas Mataram \\ Email : itsna@unram.ac.id
}

\begin{abstract}
The purpose of this study was to determine the correlation between the ability of presentation with the ability to answer oral tests on PGSD UNRAM students. The approach used in this study is a quantitative research approach to the type of correlation research. Data analysis techniques used descriptive statistical analysis and Product Moment correlation analysis. Descriptive statistical test results on presentation skills showed a mean of 79.6. While the results of descriptive statistical tests the ability to answer oral tests showed an average of 80.9. Hypothesis testing the correlation coefficient of presentation ability with the ability to answer oral tests with a significant level of 5\% obtained $r$ count $>r$ table that is $0.452>$ 0.159 and a significant value less than 0.05, 0.00. Based on the hypothesis test shows that there is a correlation between the ability of presentation with the ability to answer oral tests on PGSD UNRAM students. So Ha who stated that there was a correlation between the ability to present and the ability to answer oral tests on PGSD UNRAM students was acceptable.
\end{abstract}

Keywords: presentation skills, oral test

\begin{abstract}
Abstrak
Tujuan penelitian ini adalah untuk mengetahui korelasi anatara kemampuan presentasi dengan kemampuan menjawab tes lisan pada mahasiswa PGSD UNRAM. Pendekatan yang digunakan dalam penelitian ini adalah pendekatan penelitian kuantitatif dengan jenis penelitian korelasi. Teknik analisis data menggunakan analisis statistik deskriptif dan analisis korelasi Product Moment. Hasil uji statistik deskriptif pada keterampilan presentasi menunjukkan rerata 79,6. Sedangkan hasil uji statistik deskriptif kemampuan menjawab tes lisan menunjukkan rerata 80,9. Pengujian hipotesis koefisien korelasi kemampuan presentasi dengan kemampuan menjawab tes lisan dengan taraf signifikan 5\% diperoleh rhitung $>$ rtabel yaitu $0,452>0,159$ dan nilai signifikan yang kurang dari 0,05 yaitu 0,00 . Berdasarkan uji hipotesis tersebut menunjukkan adanya korelasi antara kemampuan presentasi dengan kemampuan menjawab tes lisan pada mahasiswa PGSD UNRAM. Sehingga Ha yang menyatakan bahwa ada korelasi antara kemampuan presentasi dengan kemampuan menjawab tes lisan pada mahasiswa PGSD UNRAM dapat diterima.
\end{abstract}

Keywords: keterampilan presentasi, tes lisan 


\section{PENDAHULUAN}

Pendidikan adalah usaha sadar dan terencana untuk mewujudkan suasana belajar dan proses pembelajaran agar siswa aktif mengembangkan potensi dirinya untuk memiliki kekuatan spiritual keagamaan, pengendalian diri, kepribadian, kecerdasan, akhlak mulia, dan keterampilan yang diperlukan dirinya, masyarakat, bangsa dan Negara (Sisdiknas, 2003:1-2). Pernyataan tersebut menjelaskan bahwa untuk tujuan luhur dari pendidikan perlu adanya usaha yang terencana. Usaha-usaha tersebut dapat tercermin dari proses pembelajaran. Pendidikan hari ini dituntut untuk memenuhi standar pendidikan abad 21. Abad 21 yang ditandai dengan perkembangan ilmu pengetahuan yang luar biasa disegala bidang, terutama bidang Information and Communication Technology (ICT) yang serba canggih dan membuat dunia ini semakin sempit. Kecanggihan teknologi ICT ini menyebabkan beragam informasi dari berbagai sudut dunia mampu diakses dengan instan dan cepat oleh siapapun dan dari manapun, komunikasi antar personal dapat dilakukan dengan mudah, murah kapan saja dan di mana saja (Syamsuri dan Ishaq 2018: 1).

Perkembangan ICT pada akhirnya berdampak pula dalam dunia pendidikan. Dengan berkembangnya ilmu pengetahuan dan ICT, maka muncullah tantangan baru yang tidak ada pada abad sebelumnya. Susanto (2010) menjelaskan bahwa ada 7 tantangan guru dalam menghadapi pembelajaran abad 21 diantaranya yaitu : 1 . Teaching in multicultural society, mengajar di masyarakat yang memiliki beragam budaya dengan kompetensi multi bahasa. 2 . Teaching for the construction of meaning, mengajar untuk mengkonstruksi makna (konsep). 3. Teaching for active learning, mengajar untuk pembelajaran aktif. 4. Teaching and technology, mengajar dan teknologi. 5. Teaching with new view about abilities, mengajar dengan pandangan baru mengenai kemampuan. 6. Teaching and choice, mengajar dan pilihan. 7. Teaching and accountability, mengajar dan akuntabilitas.

Berbagai tantangan yang dihadapi oleh guru harus dipersiapkan terlebih dahulu oleh para calon guru. Oleh karena itu mahasiswa PGSD UNRAM yang merupakan calon guru perlu dipersiapkan agar dapat menghadapi tantangan pembelajaran abad 21. Salah satu mata kuliah yang diajarkan pada program studi PGSD UNRAM ialah Pendidikan IPS SD. Ilmu Pengetahuan Sosial (IPS) merupakan ilmu yang mengkaji tentang manusia dan dunia sekelilingnya (Solihatin dan Raharjo 2008: 15). Mata kuliah tersebut membutuhkan keterampilan berkomunikasi untu membentuk hubungan anatara manusia 
dengan dunia sekelilingnya. Hal tersebut sejalan dengan cara menghadapi berbagai tantangan dalam menghadapi abad 21, hal utama yang harus dikuasai calon guru yaitu komuikasi, karena dalam proses pembelajaran guru diharuskan berkomunikasi dengan peserta didik untuk menyampaikan ide maupun gagasannya.

Penyampaian ide maupun gagasan kepada orang lain dapat dilakukan dengan berbagai cara. Salah satunya adalah melalui presentasi, presentasi adalah proses unjuk kerja oleh siswa untuk mempresentasikan materi yang telah disusun secara lengkap, ringkas, jelas, runtut, dan penuh percaya diri dengan memperhatikan faktor-faktor penunjang keefektifan presentasi (Wardani 2016: 127).

Presentasi dapat digunakan sebagai metode pembelajaran di kelas saat proses perkuliahan. Presentasi dapat membantu mahasiswa untuk membiasakan diri mengkomunikasikan ide ataupun gagasannya di depan orang lain. Dalam melaksanakan presentasi, mahasiswa perlu memiliki keterampilan, hasil penelitian Wardani (2016: 136) menghasilkan 11 aspek penilaian presentasi ilmiah yaitu : kualitas materi presentasi, (2) kelengkapan, keringkasan, kejelasan, dan keruntutan penyampaian materi presentasi, penyampaian pembuka dan penutup presentasi, (4) penggunaan media presentasi,
(5) kualitas pengutaraan tanggapan dan jawaban, (6) ekspresi fisik (postur, gerak tubuh, gesture, mimik, dan kontak mata), (7) ekspresi vokal (volume, intonasi, jeda, kecepatan, dan artikulasi), (8) ekspresi verbal (pilihan kata dan keefektifan kalimat), (9) kualitas media presentasi, (10) ketepatan waktu presentasi, dan (11) kepercayaan diri.

Kesebelas aspek yang dipaparkan dapat mempersiapkan mahasiswa sebagai calon guru menjadi sosok yang siap untuk pembelajaran abad 21. Dengan penilaian keterampilan presentasi yang baik diharapkan tujuan perkuliahan dapat tercapai. Untuk mengetahui tercapai atau tidaknya tujuan perkuliahan perlu adanya evaluasi atau penilaian pembelajaran. Penilaian adalah proses mengamati dan mengukur kegiatan belajar. Tujuannya adalah untuk mengukur seberapa baik siswa telah mempelajari konsep, untuk memahami cara belajar siswa, dan untuk memperbaiki pengajaran (Abdussakir 2006: 4).

Penilaian pembelajaran dapat dilakukan dengan beberapa teknik salah satunya tes lisan. Tes lisan merupakan suatu bentuk tes yang menuntut respon dari peserta didik dalam bentuk bahasa lisan. Peserta didik akan mengucapkan jawaban dengan kata-kata sendiri sesuai dengan pertanyaan ataupun perintah yang diberikan (Purwanto 2004 : 37). Penggunaan tes lisan memilik kelebihan dan kekurangan. 
Kelebihannya yaitu guru dapat langsung mengetahui seberapa besar materi yang diserap oleh siswa sesuai dengan kemampuan melalui gaya bahasa masingmasing dalam menyampaikan apa yang diketahui oleh siswa tersebut, sedangkan kekurangannya yaitu pelaksanaan tes lisan memerlukan waktu yang sangat lama sehingga tidak efisien (Rokhmawan 2009: 3). Pemilihan tes lisan diharapkan mengurangi kecurangan yang sering terjadi pada tes tertulis. Pemilihan tes lisan juga didasarkan pada kebutuhan calon guru untuk mengungkapkan gagasannya secara verbal. Selain membutuhkan kemampuan berbicara yang berhubungan dengan mental, tes lisan juga membutuhkan penguasaan materi agar dapat menjawab soal tes yang diberikan dosen. Hal tersebut sejalan dengan keterampilan presentasi yang membutuhkan penguasaan materi dan keterampilan berbicara di depan kelas. Perbedaan dari kedua variabel tersebut adalah pada saat presentasi, mahasiswa menghadapi dosen dan juga mahasiswa lain, hanya saja lebih fokus ke mahasiswa lain di dalam kelas. Sedangkan pada tes lisan, mahasiswa sepenuhnya bertanggung jawab menghadapi dosen yang sedang memberikan pertanyaan. Dari latar belakang yang telah dipaparkan, penulis tertarik untuk melakukan penelitian dengan judul "Korelasi antara Keteranpilan Presentasi dengan Kemampuan Menjawab Tes Lisan pada Mahasiswa PGSD UNRAM".

\section{METODE}

Pendekatan yang digunakan dalam penelitian ini adalah pendekatan penelitian kuantitatif dengan jenis penelitian korelasi. Sudjana dan Ibrahim menjelaskan mengenai pengertian studi korelasi yaitu studi yang mempelajari hubungan dua variabel atau lebih, yakni sejauh mana variasi dalam satu variabel berhubungan dengan variasi dalam variabel lain (2009: 77). Menurut Arikunto (2010: 247-248), penelitian korelasional (Correlational Studies) merupakan penelitian yang dimaksudkan untuk mengetahui ada tidaknya hubungan antara dua ata beberapa variabel. Ciri dari penelitian korelasional adalah bahwa penelitian tersebut tidak menuntut subyek penelitian yang terlalu banyak.

Populasi dalam penelitian ini adalah seluruh mahasiswa semester dua PGSD Universitas Mataram yang berjumlah 328 mahasiswa. Teknik pengambilan sampel yang dilakukan yaitu Simple Random Sampling dengan menggunakan rumus Slovin eror margin sebesar 5\%, sehingga didapatkan sampel berjumlah 180. Teknik pengumpulan data yang digunakan adalah tes lisan dan observasi. Variabel yang digunakan dalam penelitian ini terdiri dari dua variabel, yaitu variabel terikat 
kemampuan menjawab tes lisan (Y) dan variabel bebas yaitu keterampilan presentasi (X). Instrumen penelitian berupa lembar observasi dan soal tes. Lembar observasi untuk mengukur keterampilan presentasi, indikator penilaian terdiri dari lima aspek diantaranya : (1) kelengkapan, keringkasan, kejelasan, dan keruntutan penyampaian materi presentasi, (2) kualitas pengutaraan tanggapan dan jawaban, 3) ekspresi fisik (postur, gerak tubuh, gesture, mimik, dan kontak mata), (4) ekspresi vokal (volume, intonasi, jeda, kecepatan, dan artikulasi), (5) ekspresi verbal (pilihan kata dan keefektifan kalimat). Kemudian tes lisan terdiri dari 5 soal yang telah melalui uji validitas dan realibilitas. Pengujian validitas dan realibilitas didapatkan dari uji coba kepada mahasiswa di luar sampel. Uji prsayarat analisis yang digunakan yaitu uji normalitas. Teknik analisis data menggunakan analisis statistik deskriptif dan analisis korelasi Product Moment.

\section{HASIL DAN PEMBAHASAN}

Penelitian ini menyangkut beberapa aspek yang dianalisis diantarannya analisis statistik keterampilan presentasi, analisis statistik kemampuan menjawab tes lisan dan analisis korelasi antara keterampilan presentasi dengan kemampuan menjawab tes lisan. Sebelum menganalisis berbagai aspek tersebut, terlebih dahulu dibutuhkan instrumen untuk mengukurnya. Instrumen yang dibutuhkan yaitu lembar observasi keterampilan peresentasi dan lembar soal untuk menilai kemampuan mahasiswa dalam menjawab tes lisan. Lembar observasi terdiri dari berbagai indikator penilaian yang diambil dari hasil penelitian yang dilakukan oleh Wardani (2016) sehingga sudah melalui rangkaian tahapan yang menjadikan alat ukur tersebut valid. Untuk soal tes lisan, sebelum digunakan terlebih dahulu diujicobakan kepada mahasiswa diluar sampel untuk mendapatkan soal yang valid dan realiabel. Berikut hasil uji validitas dan realibilitas soal tes lisan.

Tabel 1. Rekapitulasi Uji Validitas Soal Tes Uji Coba

\begin{tabular}{|c|c|c|}
\hline $\begin{array}{c}\text { Nomor } \\
\text { Soal }\end{array}$ & $\begin{array}{c}\text { Pearson } \\
\text { Correlations } \\
\left(\mathrm{r}_{11}\right)\end{array}$ & Validitas \\
\hline 1 & .349 & Tidak Valid \\
\hline 2 & $.618^{*}$ & Valid \\
\hline 3 & .499 & Tidak Valid \\
\hline 4 & $.586^{*}$ & Valid \\
\hline 5 & $.570^{*}$ & Valid \\
\hline 6 & .349 & Tidak Valid \\
\hline 7 & $.618^{*}$ & Valid \\
\hline 8 & .499 & Tidak Valid \\
\hline 9 & $.586^{*}$ & Valid \\
\hline 10 & $.570^{*}$ & Valid \\
\hline
\end{tabular}

Data pada tabel di atas menunjukkan bahwa sebanyak 6 butir soal valid. Soal yang valid kemudian diuj realibiltas dengan cronbach's alpha. Berikut hasil uji realibilitas sola yang valid. 
Tabel 2

Hasil Uji Realibilitas

\begin{tabular}{|c|c|}
\hline $\begin{array}{c}\text { Cronbach's } \\
\text { Alpha }\end{array}$ & N of Items \\
\hline .770 & 6 \\
\hline
\end{tabular}

Dalam uji reliabilitas, digunakan batas tertentu untuk menentukan reliabel tidaknya suatu instrumen. Batasan nilai reliabilitas menurut Sekaran (1992) dalam Priyatno (2010: 98) yaitu, reliabilitas kurang dari 0,6 adalah kurang baik, sedangkan 0,7 dapat diterima, dan di atas 0,8 adalah baik. Hasil uji reliabilitas menunjukkan nilai cronbach's alpha sebesar 0,770. Mengacu pada pendapat Sekaran, nilai 0,770 berarti di atas 0,7 , sehingga instrumen soal sudah terbukti reliabel dan dapat diterima. Kemudian, setelah melakukan uji validitas dan reabilitas, peneliti menentukan 5 soal yang dibutuhkan. Maka dari 6 soal yang valid dan realiabel diambil 5 soal dengan tingkat kevalidan yang lebih tinggi yaitu no 2, 4, 5, 7 dan 8. Setelah didapatkan instrumen untuk penilaian keterampilan presentasi dan instrumen lembar soal tes lisan yang valid, langkah selanjutnya adalah melakukan analisis statistik keterampilan presentasi, analisis statistik kemampuan menjawab tes lisan dan analisis korelasi antara keterampilan presentasi dengan kemampuan menjawab tes lisan.

\section{Keterampilan Presentasi}

Seperti yang sudah dipaparkan sebelumnya, penilaian keterampilan presentasi dapat dilihat dari berbagai aspek seperti penguasaan materi, kemampuan menanggapi dan menjawab pertanyaan, ekspresi fisik, ekspresi vokal dan ekspresi verbal. Setelah melalui penilaian dengan berbagai aspek tersebut, didapatkan hasil sebagai berikut :

Tabel 3

Distribusi Frekuensi Penilaian Keterampilan Presentasi (variabel X)

\begin{tabular}{|l|l|c|c|}
\hline \multicolumn{1}{|c|}{ Nilai } & \multicolumn{1}{c|}{ Kategori } & $\mathrm{F}$ & Prosentase \\
\hline $80-100$ & Baik Sekali & 106 & $59 \%$ \\
\hline $70-79$ & Baik & 73 & $40,5 \%$ \\
\hline $60-69$ & Cukup & 1 & $0,5 \%$ \\
\hline$<60$ & Kurang & 0 & $0 \%$ \\
\hline
\end{tabular}

Dari tabel di atas dapat diketahui bahwa (1) Rentang nilai 80-100 termasuk dalam kategori sangat baik. Frekuensi mahasiswa yang memperoleh nilai $80-100$ adalah sebanyak 106 mahasiswa atau jika dipersentasekan sebesar 59 \%. (2) Rentang nilai 70-79 termasuk dalam kategori baik. Frekuensi mahasiswa yang memperoleh nilai 70-79 adalah sebanyak 73 siswa atau jika dipersentasekan sebesar 40,5 \%. (3) Rentang nilai 60-69 termasuk dalam kategori cukup. Frekuensi mahasiswa yang memperoleh nilai 60-69 sebanyak 11 mahasiswa atau jika dipersentasekan sebesar $0,5 \%$. Kemudian didapatkan nilai rata-rata keterampilan presentasi mahasiswa PGSD 
UNRAM semester II sebesar 79,6 termasuk dalam kategori baik.

\section{Kemampuan Menjawab Tes Lisan}

Seperti halnya kemampuan presentasi, hasil dari penilaian tes lisan juga dipengaruhi oleh penguasaan materi. Perbedaannya, pada saat melakukan presentasi cara mengungkapkan ide atau gagasan juga menjadi aspek penilaian seperti ekspresi fisik, ekspresi verbal dan ekspresi vokal, sedangkan pada penilaian tes lisan, cukup mahasiswa dapat menjawab pertanyaan dengan benar meskipun tidak begitu menguasai berbagai aspek ekspresi. Berikut hasil penilaian tes lisan pada mata kuliah Pendidikan IPS SD :

Tabel 4

Distribusi Frekuensi Kemampuan Menjawab Tes Lisan (variabel Y)

\begin{tabular}{|l|l|c|c|}
\hline \multicolumn{1}{|c|}{ Nilai } & \multicolumn{1}{c|}{ Kategori } & $\mathrm{F}$ & Prosentase \\
\hline $80-100$ & Baik Sekali & 114 & $63,3 \%$ \\
\hline $70-79$ & Baik & 22 & $12,2 \%$ \\
\hline $60-69$ & Cukup & 30 & $16,6 \%$ \\
\hline$<60$ & Kurang & 14 & $7,8 \%$ \\
\hline
\end{tabular}

Dari tabel di atas dapat diketahui bahwa (1) Rentang nilai 80-100 termasuk dalam kategori sangat baik. Frekuensi siswa yang memperoleh nilai 80-100 adalah sebanyak 114 mahasiswa atau jika dipersentasekan sebesar 63,3 \%. (2) Rentang nilai 70-79 termasuk dalam kategori baik. Frekuensi mahasiswa yang memperoleh nilai 70-79 adalah sebanyak 22 mahasiswa atau jika dipersentasekan sebesar 12,2 \%. (3) Rentang nilai 60-69 termasuk dalam kategori cukup. Frekuensi mahasiswa yang memperoleh nilai 60-69 sebanyak 30 mahasiswa atau jika dipersentasekan sebesar 16,6\%. Rentang nilai $<60$ termasuk dalam kategori kurang. Frekuensi mahasiswa yang memperoleh nilai $<60$ adalah sebanyak 14 mahasiswa atau jika dipersentasekan sebesar 7,8 \%. Kemudian didapatkan nilai rata-rata kemampuan menjawab soal tes lisan mahasiswa PGSD UNRAM semester II sebesar 80,9 termasuk dalam kategori sangat baik.

\section{Korelasi anatara Keterampilan Presentasi dengan Kemampuan Menjawab Tes Lisan.}

Sebelum menentukan korelasi dari kedua variavel, terlebih dahulu dilakukan uji prasyarat analisis yaitu uji normalitas data. Berikut hasil perhitungan uji normalitas dengan menggunakan uji kolmogorofSmirnov yang dihitung dengan bantuan SPSS 17.

Tabel 5. Uji Normalitas

\begin{tabular}{|c|c|c|}
\hline & & $\begin{array}{l}\text { Unstandardized } \\
\text { Residual }\end{array}$ \\
\hline \multicolumn{2}{|l|}{$\mathrm{N}$} & 180 \\
\hline \multirow{3}{*}{$\begin{array}{l}\text { Normal } \\
\text { Parameters }^{\mathrm{a}}\end{array}$} & Mean & 0 \\
\hline & Std. & \\
\hline & Deviation & 12.74882117 \\
\hline \multirow{3}{*}{$\begin{array}{l}\text { Most } \\
\text { Extreme } \\
\text { Differences }\end{array}$} & Absolute & 0.09 \\
\hline & Positive & 0.056 \\
\hline & Negative & -0.09 \\
\hline \multicolumn{2}{|c|}{ Kolmogorov-Smirnov Z } & 1.206 \\
\hline \multicolumn{2}{|c|}{ Asymp. Sig. (2-tailed) } & 0.109 \\
\hline
\end{tabular}


Hasil analisis data menyajikan nilai signifikansi sebesar 0,109. Berdasarkan kriteria pengujiannya, data berdistribusi normal jika taraf signifikasi $>0,05$ dan untuk distribusi tidak normal jika taraf signifikasi $<0,05$. Jadi dapat dikatakan bahwa data analisis diatas berdistribusi normal karena nilai signifikansi sebesar 0,109 lebih besar dari 0,05

Setelah didapatkan data hasil penilaian keterampilan presentasi dan kemampuan menjawab soal tes lisan berdistribusi normal, selanjutnya dihitung korelasi antara kedua variabel dengan menggunakan rumusan korelasi Product Moment dibantu dengan program SPSS 17. Berikut hasil analisis korelasinya.

Tabel 6. Uji Hipotesis (Korelasi

\begin{tabular}{|l|l|r|r|}
\hline \multirow{2}{*}{$\begin{array}{l}\text { Nilai } \\
\text { Keterampilan } \\
\text { Presentasi }\end{array}$} & $\begin{array}{l}\text { Pearson } \\
\text { Correlation }\end{array}$ & \multicolumn{1}{|c|}{$\begin{array}{c}\text { Nilai } \\
\text { Keterampilan } \\
\text { Presentasi }\end{array}$} & \multicolumn{1}{c|}{$\begin{array}{c}\text { Nilai Tes } \\
\text { Lisan }\end{array}$} \\
\cline { 2 - 4 } & $\begin{array}{l}\text { Sig. (2- } \\
\text { tailed) }\end{array}$ & 1 & $.452^{* *}$ \\
\cline { 2 - 4 } & $\mathrm{N}$ & & 0 \\
\hline \multirow{2}{*}{$\begin{array}{l}\text { Nilai Tes } \\
\text { Lisan }\end{array}$} & $\begin{array}{l}\text { Pearson } \\
\text { Correlation }\end{array}$ & 180 & 180 \\
\cline { 2 - 4 } & $\begin{array}{l}\text { Sig. (2- } \\
\text { tailed) }\end{array}$ & $.452^{* *}$ & \\
\cline { 2 - 4 } & $\mathrm{N}$ & 0 & 1 \\
\hline
\end{tabular}

Berdasarkan tabel tersebut, diketahui nilai signifikansi sebesar 0,00 sehingga dilihat dari dasar pengambilan keputusan pada penelitian ini yaitu jika nilai signifikan $<0,05$ maka $\mathrm{H}_{\mathrm{a}}$ diterima dan $\mathrm{H}_{\mathrm{o}}$ ditolak, artinya ada korelasi yang signifikan antara keterampilan presentasi dengan kemampuan menjawab soal tes lisan. Sebaliknya, apabila nilai signifikan $>0,05$ maka $\mathrm{H}_{\mathrm{a}}$ ditolak dan $\mathrm{H}_{\mathrm{o}}$ diterima, artinya tidak ada korelasi yang signifikan antara antara keterampilan presentasi dengan kemampuan menjawab soal tes lisan.

\section{KESIMPULAN}

Berdasarkan hasil analisis data dan pembahasan yang telah diuraikan, maka dapat disimpulkan sebagai bahwa hasil analisis data statistik deskriptif menunjukkan bahwa rata-rata hasil keterampilan presentasi sebesar 79,6 yang masuk dalam kategori baik. Berdasarkan uji statistik deskriptif sebanyak 59\% mahasiswa masuk dalam kategori baik sekali, 40,5 \% masuk kategori baik dan 0,5\% masuk kategori cukup. Hal ini menjelaskan bahwa sebagian besar nilai keterampilan presentasi mahasiswa semester II PGSD UNRAM dalam kategori baik sekali.

Hasil analisis data statistik deskriptif menunjukkan bahwa rata-rata hasil kemampuan menjawab soal tes lisan sebesar 80,9 yang masuk dalam kategori baik sekali. Berdasarkan uji statistik deskriptif sebanyak 63,3\% mahasiswa masuk dalam kategori baik sekali, 12,2 \% masuk kategori baik, 16,6\% masuk kategori cukup dan 7,8\% 
masuk dalam kategori kurang. Hal ini menjelaskan bahwa sebagian besar nilai kemampuan mahasiswa semester II PGSD UNRAM dalam menjawab soal tes lisan masuk kategori baik sekali.

Hasil uji hipotesis koefisien korelasi dengan sampel 180 mahasiswa dan taraf signifikan $5 \%$ diperoleh $\mathrm{r}$ hitung $>\mathrm{r}$ tabel yaitu $0,452>0,159$ dan nilai signifikan yang kurang dari 0,05 yaitu 0,00. Berdasarkan uji hipotesis tersebut menunjukkan adanya korelasi antara kemampuan presentasi dengan kemampuan menjawab tes lisan pada mahasiswa semester II PGSD UNRAM. Sehingga Ha yang menyatakan bahwa ada korelasi antara kemampuan presentasi dengan kemampuan menjawab tes lisan pada mahasiswa PGSD UNRAM dapat diterima.

\section{DAFTAR PUSTAKA}

Abdussakir. (2006). Pengembangan Evaluasi Pembelajaran Berbasis Kompetensi. Workshop Manajemen Madrasah, KBK, Dan Pembelajaran Mafikibb Guru Mts/MA Se-Magetan Selatan Dan Barat"

Arikunto, S. (2010). Prosedur Penelitian Suatu Pendekatan Praktik. Jakarta: Rineka Cipta.

Purwanto, N. (2004). Prinsip-Prinsip Dan Teknik Evaluasi Pengajaran. Bandung : Remaja Rosdakarya
Rokmawan. (2009). Perbedaan Hasil Belajar Antara Tes Tertulis Dengan Tes Lisan Pokok Bahasan Konstruksi Pondasi Dangkal Pada Siswa Program Keahlian Teknik Gambar Bangunan Tingkat X Smk Negeri 5 Semarang. SKRIPSI : Universitas Negeri Semarang.

Solihatin, E. \& Raharjo. (2008). Cooperative Learning Analisis Model Pembelajaran IPS. Jakarta: Bumi Aksara.

Sudjana,N \& Ibrahim. (2009). Penelitian Dan Penilaian Pendidikan. Cet.IX; Bandung: Sinar Baru Algesindo.

Syamsuri, A. S. \& Ishaq. (2018). Makalah : Guru, Generasi Z, Dan Pembelajaran Abad 21:

Http://Www.Unismuh.Ac.Id/Wp-

Content/Uploads/2018/05/Tantangan -Guru-Generasi-Z-Dan-

Pembelajaran-Abad-21.Pdf

Wardani, H. (2016). Pengembangan Instrumen Asesmen Presentasi Ilmiah Di Sma. Journal MUADDIB Vol.06 No.02, ISSN 2540-8348, hal.136, diakses tanggal 4 Agustus 2019 